\title{
Social bonding, early school leaving, and delinquency
}

Citation for published version (APA):

Traag, T., Marie, O., \& van der Velden, R. K. W. (2010). Social bonding, early school leaving, and delinquency. Researchcentrum voor Onderwijs en Arbeidsmarkt, Faculteit der Economische Wetenschappen. ROA Research Memoranda No. 14 https://doi.org/10.26481/umaror.2010014

Document status and date:

Published: 01/01/2010

DOI:

10.26481/umaror.2010014

Document Version:

Publisher's PDF, also known as Version of record

\section{Please check the document version of this publication:}

- A submitted manuscript is the version of the article upon submission and before peer-review. There can be important differences between the submitted version and the official published version of record.

People interested in the research are advised to contact the author for the final version of the publication, or visit the DOI to the publisher's website.

- The final author version and the galley proof are versions of the publication after peer review.

- The final published version features the final layout of the paper including the volume, issue and page numbers.

Link to publication

\footnotetext{
General rights rights.

- You may freely distribute the URL identifying the publication in the public portal. please follow below link for the End User Agreement:

www.umlib.nl/taverne-license

Take down policy

If you believe that this document breaches copyright please contact us at:

repository@maastrichtuniversity.nl

providing details and we will investigate your claim.
}

Copyright and moral rights for the publications made accessible in the public portal are retained by the authors and/or other copyright owners and it is a condition of accessing publications that users recognise and abide by the legal requirements associated with these

- Users may download and print one copy of any publication from the public portal for the purpose of private study or research.

- You may not further distribute the material or use it for any profit-making activity or commercial gain

If the publication is distributed under the terms of Article $25 \mathrm{fa}$ of the Dutch Copyright Act, indicated by the "Taverne" license above, 


\section{Social Bonding, Early School Leaving, and Delinquency}

Tanja Traag

Olivier Marie

Rolf van der Velden

\section{ROA Research Memorandum}

ROA-RM-2010/14

Research Centre for Education and the Labour Market Maastricht University

P.O. Box 616,6200 MD Maastricht, The Netherlands

$\mathrm{T}+31433883647 \mathrm{~F}+31433884914$

secretary-roa-sbe@maastrichtuniversity.n www.roa.nl 


\title{
Social Bonding, Early School Leaving, and Delinquency
}

\author{
Tanja Traag \\ Olivier Marie \\ Rolf van der Velden
}

ROA-RM-2010/14*

December 2010

Research Centre for Education and the Labour Market

Maastricht University

P.O. Box 616, 6200 MD Maastricht, The Netherlands

$\mathrm{T}+31433883647 \mathrm{~F}+31433884914$

secretary-roa-sbe@maastrichtuniversity.nl

www.roa.nl

\footnotetext{
* The ROA Research Memorandum Series was created in order to make research results available for discussion, before those results are submitted for publication in journals.
} 


\section{Abstract}

\section{Social Bonding, Early School Leaving, and Delinquency ${ }^{* *}$}

In this paper we investigate how successful social bonding theory is at predicting juvenile delinquency and school dropout behaviour. We adopt a simple dynamic approach which assumes that past involvement in risky behaviour reduces individual restraints for future participation in risky behaviour. We use a ten years education panel following Dutch adolescents who participated in a survey in their first year of high school in 1999. This information was matched to annual information on police arrests based on registry data. Our results show that school performance (as measured by test scores) is the key social bond element preventing young people from engaging in risk behaviour. We also find that involvement in past risky behaviour increases the likelihood of future missteps and that the protective influence of school performance is mitigated.

Keywords: social bonding theory, early school-leaving, juvenile delinquency

$\begin{array}{ll}\text { Tanja Traag } & \text { Olivier Marie } \\ \text { CBS } & \text { ROA } \\ \text { P.O. Box } 4481 & \text { Maastricht University } \\ 6401 \text { CZ Maastricht } & \text { P.O. Box 616 } \\ \text { The Netherlands } & 6200 \text { MD Maastricht } \\ \text { ttrg@cbs.nl } & \text { The Netherlands } \\ & \text { o.marie@maastrichtuniversity.nl }\end{array}$

Rolf van der Velden

ROA

Maastricht University

P.O. Box 616

6200 MD Maastricht

The Netherlands

r.vandervelden@maastrichtuniversity.nl

\footnotetext{
** We thank Charlotte Buchner, Bart Golsteyn, Rianne Kloosterman, Olga Skriabikova, and participants at the American Society of Criminology 2010 Annual Meeting for comments on earlier versions of this paper. Olivier Marie would like to thank the Executive Research Agency of the European Union for funding under the Marie Curie grant IEF-252572.
} 


\section{I - Introduction}

Social control was introduced as a theoretical framework to explain the causes of delinquency among juveniles (Hirschi, 1969). The theory claims that social bonds which young people form with, for instance their schools, are strong predictors of whether or not they will become criminally active. The extent of social control is therefore dependent on the quality and strength of social bonding. It is now however relatively accepted that social control cannot alone explain youth delinquency and one must also consider the importance of a person's capacity for self control. This is perhaps best summed up by Gottfredson and Hirschi (1990) when they state that: "Combining the two ideas thus merely recognizes the simultaneous existence of social and individual restraints on behaviour" (pp. 87-88). The implication of this change in perspective is significant since it can now be asserted that for given levels of social bonding we could observe very different behavioural outcomes - such as delinquency and early school leaving - which actually result from differences in individual propensity for self control. There have been so far surprisingly few attempts to distinguish and measure the importance of these two possible channels to explain participation in risky behaviour by youth.

In this paper we therefore propose to investigate how successful social bonding theory is at predicting juvenile delinquency and school dropout behaviour. To account for the influence of self control capacity we adopt a simple dynamic approach which assumes that past involvement in risky behaviour reduces individual restraints for future participation in risky behaviour. We empirically test these hypotheses by first constructing four measures of school social bonding (i.e. attachment, commitment, belief, and performance) from a large survey of secondary school pupils. This is then matched to administrative micro-data containing both educational and offending information for these individuals from adolescence to early adulthood. We also have detailed family background characteristics to control for non school related bonding factors which may simultaneously affect delinquency and drop out behaviour.

The nature of our data enables us to consider a dynamic setting which estimates the impact of social bonds on sequential participation in risky behaviour: delinquency before leaving school; dropping out of school with no qualification; and delinquency after leaving school. We also analyse how sensitive our results are to the inclusion of participation in one of these behaviours in the past and how our social bonds estimates differ across youths who were 
involved or not previously. This approach allows us to disentangle the importance of social and individual restraints on risky behaviour. Our main finding is that school performance is consistently the most important social bond protecting against participation in any of our three risky behaviour outcomes. It is also the only bonding measure which remains significant throughout once we account for family background and previous behavioural patterns. We finally also find significant differences in the importance of school performance levels in predicting dropout behaviour whether a student was arrested before leaving school or not.

The rest of the paper is structured as follows: Section II presents a short literature review and sets up the theoretical framework which forms the basis for our empirical analysis. Section III describes the data used for this study. Section IV gives some descriptive statistics and sets up the modelling strategy. Section V reports and discusses our results. The final section contains concluding remarks.

\section{II - Literature Review and Theoretical Framework}

Hirschi (1969) argued that delinquency among adolescents could be predicted by looking at the strength and quality of the bonds they formed with, among other social institutions, their schools. In his theory, later labelled Social Bonding Theory, Hirschi defined four main categories of social bonds (Burfeind and Bartusch 2010; Hirschi 1969;). First is attachment defining the quality of the bond between students and their school which refers to the emotional ties to teachers and school officials. Second is commitment, which refers to the desire to succeed and the degree of commitment to academic pursuits. Third is belief, which refers to believing that school rules are fair and evenly enforced. The fourth and final element is involvement which considers attendance and attentiveness in the classroom and which we will refer to as performance henceforth.

A number of studies have found evidence that a lack of social bonding is directly associated with delinquent behaviour (Gottfredson and Hirschi 1990; Jenkins 1995; Krohn and Massey 1980; Thornberry, Moore, and Christenson 1985). Other studies applied Hirschi's theory to other forms of illicit behaviour, such as drug and alcohol abuse (Akers and Lee 1999; Eitle and Eitle 2007; Ketterlinus and Lamb 1994), and ethical rule breaking (Sims 2002). More related 
to our research, Jenkins $(1995,1997)$ considered the effect of school bonding on delinquency at school and Jarjoura (1993) the impact of dropping out of school on future offending. We will here combine these two approaches to measure how the impact of social bonds on risky behaviour evolves with an individual's past participation in such activities.

Developmental criminologists claim that offenders who display delinquent behaviour in the early stages of their life course are the ones most likely to become persistent offenders showing consistent patterns of delinquency. However, not all young offenders become lifetime criminals. In her developmental taxonomy, Moffitt (1993) makes a distinction between lifecourse-persistent and adolescence limited antisocial behaviour, arguing that adolescents start antisocial behaviour because they are attracted by the independence and autonomy of peers that displayed problematic behaviour in early life. They may nevertheless be still bonded enough to their parents, their school and other social institutions to stop engaging in risky behaviour when they enter adulthood. This developmental approach from the criminology literature is of interest here as it highlights the importance of adopting a dynamic approach to understand delinquency.

In this paper we investigate the persistence of antisocial behaviour from adolescence through early adulthood while keeping track of how Hirschi's four elements of social bonding influence this behaviour. The focus here is on school bonds which we argue will also reflect bonding strength to other social institution, such as work, later in life. We also want to distinguish these from non-school related bonding to the family and do this by accounting for a large number of individual characteristics as described in the next section.

This study considers two main forms of risky behaviour, juvenile delinquency and early school-leaving. First, we analyze how delinquency while still in school is influenced by social bonding, as measured by four elements: attachment, commitment, belief, and performance. Second, we analyze how social bonding affects early school-leaving and how this relationship may be affected by prior delinquent behaviour. Third, we estimate the impact of social bonding on offending after having left school. We consider how the effect of the four social bonds may change with delinquent behaviour while at school and/or the decision to drop out without secondary education qualification. We assume throughout that decreased social bonding increases the likelihood of our three risky behaviour outcomes but crucially hypothesize that this relationship may change over time, and especially once we take into account previous decisions to participate or not in such activities. 
Following Gottfredson and Hirschi's (1990) argument about the relevance of self-control, we might anticipate that social bonding is not as strong a predictor of adult offending as of early delinquency and school-leaving. This is assuming that participation in risky behaviour in the past decreases one's self-control which in turn increases opportunities for future delinquency. Therefore, we expect to find significantly smaller negative effects of social bonding for early delinquents as well as for early school-leavers. A strong effect of past risky behaviour would however suggest that gradual depreciation of self control capacity (e.g. patience propensity) is crucial to understanding educational and criminal participation decisions of young adults. We also want to assert if 'returns' to our measures of social bonds are different for individuals with past participation in risky behaviour as this may have important policy implications.

\section{III - Data}

\section{Student sample}

We will use a unique dataset created by matching survey and administrative information on young individuals to explore the underlying mechanism between how social bonding may explain the relationship between early school-leaving and juvenile delinquency before and after leaving school. The basic sample is formed by a large representative longitudinal survey of Dutch youth carried out by Statistics Netherlands (CBS). This survey, the Secondary Education pupil Cohort 1999 (VOCL'99), consists of 19,391 students from a random sample of almost 400 schools who were in the first grade of high school in 1999/2000.

To facilitate the matching of survey information to administrative data, Statistics Netherlands provides all respondents with a unique identification number that is linked to the social security number. This enables us to match our cohort to the basic pupils register which is kept by DUO (Dienst Uitvoering Onderwijs, i.e. the body that administers student grants and loans on behalf of the Dutch Ministry of Education) and thus follow the educational career of VOCL'99 survey respondents from the school years 1999/2000 to 2008/09 and gather information about which grade the students were enrolled in during each successive year. We can therefore determine the educational level attained at any time, to see for example if the students had to repeat classes, and crucially if they dropped out of school altogether. 
Furthermore, general ability tests were administered at the time of the survey giving us a good measure of their school performance level at the start of secondary school. A written questionnaire was also given to the parents of the surveyed students with the aim of collecting information about their families and the pupils.

In this paper we want to gain better understanding of the mechanisms that underlie the relationship between early school-leaving and delinquent behaviour among juveniles both before and after leaving school. Therefore we will focus only on those students in our sample that were no longer enrolled in education by the 2008/09 school year since we will have measures of delinquency both before and after leaving school for this population. This leaves us with 7,588 students who had left school with or without a starter's qualification for our analysis ${ }^{1}$.

\section{Delinquency information}

To obtain information about potential delinquent behaviour of our students, the individuals in VOCL'99 were linked to data on all crime suspects in the Netherlands between 1996 and 2007. This information was extracted from the Suspects Identification System (HKS) which is updated annually by the National Police Services Agency. A suspect is a person who is charged with a crime. A person can be charged one or several times a year and one summons may include various offences. The data refers to suspects of criminal offences which does not automatically mean that this person is convicted. However, an estimated 90 percent of suspects are found guilty at a later stage or are offered a transaction. ${ }^{2}$ More importantly, those that were found not to be guilty were removed from the registration (Blom et al. 2005). An individual is therefore considered to have participated in delinquent behaviour if he/she was arrested at least once in a certain year.

\section{The Dutch educational system}

The Dutch educational system is highly stratified (see figure A in the appendix for an overview). To measure low educational achievement we use the 1993 Dutch Ministry of Education definition of the minimum level of education a person should acquire to be successful on the labor market: the 'starter's qualification' (startkwalificatie in Dutch). This concept does not amount to an actual certificate, but it is widely used for political and research purposes to identify youths with low educational achievement. Research has shown that those without a 
starter's qualification are on average much more likely to be unemployed and receive significantly lower wages (Allen and Meng 2010). Those who leave school without a diploma of upper secondary vocational education (MBO) or upper secondary general education (HAVO or VWO) as well as those that attain lower secondary general education (VMBO) are considered not to have obtained a starter's qualification. In our analysis we will therefore consider early school-leavers or dropouts to be individuals who did not attain one of these educational qualification before they left school.

\section{Measurement of social bonds}

The data used for this paper were not originally collected with the intention of measuring nor testing Hirschi's social bonding theory. Therefore constructs of the four elements of social bonding had to be based on the available information contained in the questionnaire administered in January 2000 while students were in first grade of secondary school (aged 12 to 13 years old). Several studies have tried to capture the elements of the social bond and many have criticized Hirschi's initial conceptualization. One important critique came from Krohn and Massey (1980) who argue that Hirschi's distinction between commitment and involvement is unclear. In their opinion the temporal dimension of school involvement (i.e. time used to do homework and investing time in school) should be conceptualized as commitment, causing them to construct only three elements of the social bond. A second issue they raised was that Hirschi employed test scores as a measure of attachment to school making the concept ambiguous. In this study we conceptualize all four social bonds largely based on the original works of Hirschi but with a number of alterations to take into account past criticism. Table 1 describes how our measures generally compare to the original concepts.

[Table 1 about here]

Our measures of the four elements of social bonding were constructed using the following information:

- Attachment (Cronbach's alpha $=.81)$ is a 10-item index indicating the responses to questions such as:"In our class students are nice to each other" and "In our class there is a pleasant atmosphere". 
- Commitment (Cronbach's alpha $=.74$ ) is an 9-item index indicating the responses to questions like: "I study much better at home when I'm worried about failing" and "I always try to do my homework as good as possible".

- Belief (Cronbach's alpha $=.62$ ) is a 2-item index indicating the responses to the following questions: "In our class teachers treat you fair" and "In our class teachers are really interested in the students".

- Performance is an index based on three subtests taken in the first months of secondary school that measure the students' aptitude in arithmetic/mathematics, text comprehension and information processing skills.

The indexes and scores for the four elements were all normalized to a scale with a minimum of 0 and a maximum of 100 . See table B in the appendix for a full list of items used.

\section{Risky behaviour outcomes}

We have three measures of the risky behaviour youths may get involved in:

- Crime before school-leaving is a dummy variable indicating if the student had been arrested by the police before the date he or she left school ${ }^{3}$.

- Early school-leaving is a dummy variable indicating if a student left school without a starter's qualification. Young people who leave education without a basic qualification are labelled early school-leavers.

- Crime after school-leaving is a dummy variable indicating if the student was arrested by the police on or after the date of leaving school.

\section{Personal characteristics}

Personal background variables we have available from the VOCL'99 survey include gender, ethnicity, age when left school, parental religion, and parental marital status at the start of secondary school. We also have information on parental educational level, parental reading behaviour as a proxy for cultural capital from the 2000 parental questionnaire and parental income in 2005 from the Annual Income Registry that is kept by Statistics Netherlands and is based on information from the Dutch Tax Administration. Some of these characteristics are missing for certain survey participants when parents did not answer all questions. For these 
individuals we will therefore input background characteristic means and include missing dummies to capture potential selection when responding to the survey.

\section{IV - Descriptives and Modelling}

\section{Descriptive statistics}

Table 2 shows the distribution of the four social bond elements and of the background variables for the total sample as well as for those who were involved or not in one of the three risky behaviours of interest. The results generally support the assumption that low social bonding is correlated with higher levels of juvenile delinquency and early school-leaving. There are however some striking differences between delinquency before and delinquency after leaving school. While attachment, commitment, belief, and performance are all inversely related to delinquency before school leaving, for delinquency after leaving school we only observe a significant negative relationship with school attachment and school performance. Early schoolleaving is negatively linked to all four elements of social bonding except school commitment; early school-leavers have significantly lower scores on school attachment, belief and performance than those that those that left school with a basic qualification.

[Table 2 about here]

Table 2 also shows the distribution of our background variables for the individuals in our samples who participated or not in our three measures of risky behaviour and their respective differences (the $\Delta$ columns). Levels of criminal participation and early school leaving are quite high because this is a sub-sample of the original student population which left education relatively young. As in most of the literature we see that male and those with foreign born parents are significantly more at risk of being delinquents as well as being early school-leavers. Parental religion and marital status also account for some of the differences in participation in risky behaviour. There is also a significant negative relationship between levels of parental education, income, and reading behaviour with our three outcomes of interest.

The final row of Table 2 reports the differences in average age when leaving school between individuals who participated in risky behaviour or not. Our early school leavers are 
slightly older and this reflects the impact of repeating classes on the likelihood of obtaining a starter's qualification. Interpreting the difference in age left school for the two delinquency measures is much more complex. This is because, since all our students are of relatively the same age cohorts, we have by construction more or less time to observe an arrest before or after leaving school depending on the age they did so. This is but one of the issues we will address in our modelling strategy which we turn to now.

\section{Modelling strategy}

We can start our analysis by estimating the following simple logistic regression equation where $\beta_{0}$ is a constant and $u$ an error term:

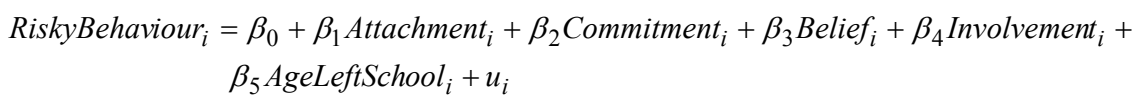

For each individual $i$ we have three different dummies for participation or not in RiskyBehaviour (i.e. delinquency before school leaving, dropping out without starter's qualification, and delinquency after school leaving). As AgeLeftSchool will mechanically increase the chances of observing more or less delinquency pre or post school leaving, we control for this in equation (1) and all other specifications. The key coefficients here are the four $\beta$ s which are estimates of the impact of the four measures of social bonds on the likelihood of participation in the three risky behaviours of interest.

The descriptive statistics in Table 2 showed that individual and family characteristics affect both school bonding and risky behaviour participation. We therefore estimate:

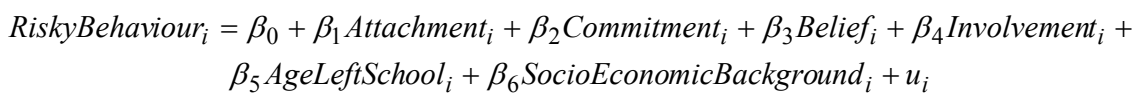

in which we also include all the background variables we have available to obtain $\beta$ s which take into account possible simultaneous associations (which appear relevant from the correlations reported in Table $\mathrm{C}$ of the Appendix). This is also important to rid our estimates of the impact of family bonding as much as possible considering our focus on school social bonding factors. 
The models we will estimate will be more dynamic in nature and also control for the effect of past participation in risky behaviour on future participation in risky behaviour.

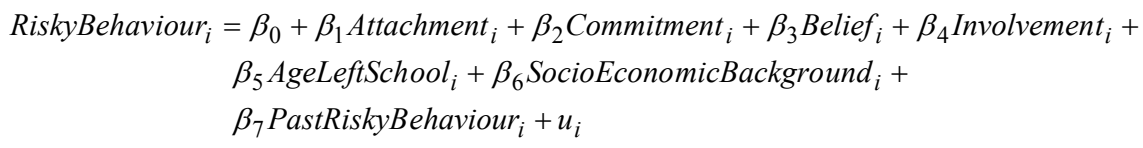

This will give us estimates of our four social bonding measures for the likelihood of being an early school leaver whether or not the individual was criminally active before dropping out. We adopt the same approach to estimate the impact of school attachment, commitment, belief, and performance on crime after leaving school controlling first for crime before leaving school and then also for dropping out without a qualification.

Our final models consider the addition of interactions between the four social bond measures and past participation in risky behaviour.

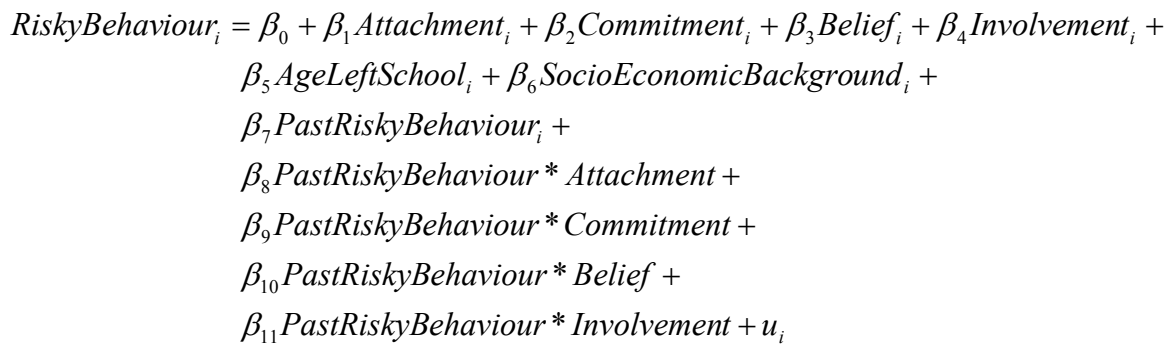

This specification will give us estimates of the impact of the four social bonding measures on early school leaving specifically for individuals who were criminally active before dropping out. We will do the same for crime after leaving school with interaction of the social bond measures with being arrested before leaving school and/or leaving without a starter's qualification. We expect these modelling strategies to enable us to estimate the returns to differences in strength of social bonding in explaining risky behaviour participation when levels of individual self control are deteriorating as proxied by past risky behaviour participation. .

\section{V - Results}




\section{Effects of social bonding on juvenile delinquency and early school-leaving}

The simple model described by equation (1) above is reported for our three outcomes: crime before school leaving, early school leaving, and crime after school leaving in columns (1), (3), and (6) of Table 3. The estimated $\beta$ s suggest that differences in school performance have the strongest negative influence on the likelihood of participating in all types of risky behaviour. For example in column (1), a unit change in this social bonding measure results in a 2.1 percentage reduction in the chances of committing a crime before leaving school. We also see that higher levels of school belief are linked to lower probabilities of arrest before leaving school and of dropping out without a starter's qualification. Finally we observe that school attachment reduces the chance of finishing school without a starter's qualification. The results are almost unchanged, if somewhat mitigated, once we include controls for background variable in columns (2), (4), and (7). The main difference is that the coefficient on attachment is halved and does no longer significantly explain differences in crime after school-leaving.

[Table 3 about here]

Inclusion of participation in past risky behaviours significantly predicts early school leaving, column (5), and crime after school leaving, columns (8) and (9). The estimates of the social bond impacts become relatively smaller. As might be expected higher school performance makes it much less likely that students drop out without a starter's qualification. Perhaps less obvious is the observation that higher levels of this social bond leads to a lower probability of crime after school leaving - a 1.1 percent reduction per unit increase in test scores - even after controlling for dropping out and committing an offence in the past.

In general we can conclude from the results reported in Table 3 that social bonding is negatively linked to both delinquency before and after school-leaving and the risk of early school-leaving. However, not all elements of social bonding have proven to be of equal importance and our more stringent modelling specifications suggest that school performance is the one that matters in the end. Our results also make it clear that past risky behaviour is a very strong predictor of future risky behaviour and gives credence to theories that highlight individual as well as social restraint factors. 


\section{Interaction effects}

To measure if the 'returns' to our measures of social bonds are different with past participation in risky behaviour we now turn to models which include interaction terms between the elements of social bonding and the two first risky behaviour events we observe (i.e. arrested before left education and early school leaving). This is presented in Table 4 for both the risk of being an early school-leaver in column (2) and the risk of being arrested after school-leaving columns (4) to (6). We also present in columns (1) and (3) the results from the full model estimated in Table 2 for comparison.

[Table 4 about here]

The most striking result here is the significant interaction of crime while at school and school performance. The main effect for school performance (i.e. -0.040) represents the protective effect of this social bond for students who were not arrested. The interaction term (0.024) indicates that the protective effect of school performance for students that were arrested before leaving school is much smaller namely $-0.040+0.024=-0.016$.

The interaction effect is depicted in Figure 1 showing the mean probability of leaving school early by ones school performance level for those that did commit an offence versus those that did not commit any offence. The figure shows that although the probability of being an early school leaver when having a low school performance score is about equal, this probability declines much more rapidly for those pupils that were not arrested before leaving school and remains much lower compared to students that were arrested. This indicates that although school performance has a highly negative impact on early school leaving for all individuals, it is a much weaker predictor of drop-out behaviour for those who committed an offence while still enrolled in school. In other words, early criminal involvement appears to strongly reduce the effect of good educational performance as a social bond preventing early school leaving.

[Figure 1 about here]

In column (4) we include interaction effects for the social bonds with criminal activity before school-leaving to explain future offending behaviour. In column (5) we remove these 
interactions and add the interactions between the four social bonds and early school-leaving. The results in column (5) show a significant interaction effect indicating that the risk of being arrested after school is much less influenced by school performance for early school-leavers than for those that did attain a starter's qualification. However, this coefficient is only marginally significant and is no longer significant when we consider crime before school as well. Finally we combine both sets of interactions in column (6) to explain crime after school leaving. The results suggest that there are no significant differences in the 'returns' to social bonds across groups with distinct experiences in past risky behaviour since none of our interaction terms is significant (although they point in the right direction, that is lower returns for students that were engaged in past risky behaviour).

\section{VI - Conclusion}

In this paper we attempted to measure how far social and self control theories are able to predict participation in risky behaviour. In our analyses we found support for Hirschi's (1969) theory that social bonding is an important protective factor for both delinquencies before and after school-leaving and the risk of dropping out without a qualification. However not all elements of social bonding have proven to be of equal importance. In general we can say that it is mainly school performance that matters. At the same time our results make it clear that past risky behaviour is a very strong predictor of future risky behaviour and gives credence to theories that highlight individual as well as social restraint factors. This is in line with Gottfredson and Hirschi's (1990) argument on the importance of one's capacity for self-control as an explanation

of why some individuals engage in risky behaviour and others do not. Thus, both social bonding theory and self control approaches help us to better understand why certain young people participate in youth delinquency, leave school under qualified and may sometimes eventually become adult criminals.

The question remains how to best interpret these findings to prevent adolescents from lapsing from one form of risk behaviour into another? They primarily suggest that increasing school performance levels could significantly decrease risky behaviour. Targeting the poorest performers at an early age should therefore be advocated as it appears to be the most efficient means to reducing their sequential participation in all forms of risky behaviour. This conclusion 
must however be mitigated by the findings from the interaction specifications we considered. They show that the returns to higher school performance levels are less important for students who were arrested while still at school compared to those pupils who were not involved in criminal activity. This would suggest that investment in the improvement of school performance to reduce adolescent risky behaviour should be coupled with policies preventing risk behaviour of children and young adolescents in order to increase their self-control and the returns to school bonding. 


\section{Notes}

1 - Students that had deceased (66), were seriously ill (22) or had moved abroad within the 1999/ 00-2008/ 09 period (254) were removed from the sample. In some cases the link to the social security number could not be made and therefore the respondent could not be given an identification number. These respondents were also removed from the sample (24). Finally we excluded all students that were born before 1986 or after 1987 (832). These were students that had either skipped a grade in primary school or repeated more than one grade by the time of the survey and were thus either older or younger than could be expected of a cohort of first graders.

2 - A transaction can prevent prosecution, if certain conditions set by the police or the public prosecutor are met, e.g. paying an amount of money (fine). Data on various types of crimes, such as economic and environmental offences and social security fraud are usually not entered into the HKS and therefore underrepresented in the figures. 


\section{Notes on the authors}

Tanja Traag is a researcher at Statistics Netherlands in Heerlen. Her current research interests include the transition from school to work, especially short and long term effects of early school-leaving.

Dr. Olivier Marie is a post-doctoral fellow at the Research Centre for Education and the Labour Market (ROA) at Maastricht University and Associate at the Centre for Economic Performance at the London School of Economics. His main research interests are in economics of crime, applied econometrics, economics of education and public economics.

Prof. Rolf van der Velden is head of the Division 'Education and Occupational Career' at the Research Centre for Education and the Labour Market (ROA) at Maastricht University. His current research interests include international comparisons in the transition from school to work, skills development and effect of skills on labour market outcomes. 


\section{References}

Akers, R. L. and G. Lee (1999). "Age, Social Learning, and Social Bonding in Adolescent Substance Use." Deviant Behavior: An Interdisciplinary Journal, 19: 1-25.

Allen, J. and C. Meng (2010). Voortijdig schoolverlaters: aanleiding en gevolgen. Maastricht, Researchcentrum voor Onderwijs en Arbeidsmarkt (ROA).

Blom, M., J. Oudhof, R.V. Bijl, and B.F.M. Bakker (2005). Verdacht van criminaliteit. Allochtonen en autochtonen nader bekeken. Den Haag/Voorbyrg, CBS/WODC.

Burfeind, J. and D. J. Bartusch (2010). Juvenile Delinquency: An Integrated Approach. Sudbury, MA, Jones \& Bartlett Learning.

Eitle, T. M. and D. J. Eitle (2007). "School commitment and alcohol use: The moderating role of race and ethnicity." Education Policy Analysis Archives 15(22): 1-17.

Farrington, D. P. (1995). "The development of offending and antisocial behaviour from childhood: key findings from the Cambridge study on delinquent development." Journal of Child Psychology and Psychiatry 36: 929-964.

Gottfredson, M. R. and T. Hirschi (1990). A general theory of crime. Stanford, CA, Stanford University Press.

Hirschi, T. (1969). Causes of delinquency. Berkeley, University of California Press.

Jarjoura, G. R. (1993). "Does dropping out of school enhance delinquent involvement? Results from a large-scale national probability sample." Criminology 31(2): 149-172.

Jenkins, P. H. (1995). "School Delinquency and School Commitment." Sociology of Education 68(3): 221-239. 
Jenkins, P. H. (1997). "School Delinquency and the School Social Bond." Journal of Research in Crime and Delinquency 34(3): 337-367.

Ketterlinus, R. D. and M. E. Lamb (1994). Adolescent problem behaviors: issues and research. Hillsdale, NJ, Lawrence Erlbaum

Krohn, M. D. and J. L. Massey (1980). "Social Control and Delinquent Behavior: An Examination of the Elements of the Social Bond." The Sociological Quarterley 21(Autumn 1980): 529-543.

Loeber, R. (1990). "Development and risk factors of juvenile antisocial behavior and delinquency." Clinical Psychology Review, 10: 1-41.

Loeber, R. and M. LeBlanc (1990). Towards a developmental criminology. Crime and Justice: A Review of Research. M. T. N. Morris. Chicago, university of Chicago Press. 12: 375-473.

Moffitt, T. (1993). "Adolescence-limited and life-course-persistent antisocial behavior: a developmental taxonomy." Psychological Review, 4: 674-701.

Sims, R. L. (2002). "Ethical Rule Breaking by Employees: A Test of Social Bonding Theory " Journal of Business Ethics 40(2): 101-109.

Thornberry, T. P., M. Moore, and R.L. Christenson (1985). "The Effect of Dropping out of high school on subsequent criminal behavior." Criminology 23: 3-18. 
Table 1: Conceptualization of the Four Elements of Social Bonding

\begin{tabular}{|l|l|l|}
\hline & Original concept by Hirschi (1969) & Concept as used in this paper \\
\hline Attachment & $\begin{array}{l}\text { The quality of the bond between students and their school } \\
\text { which refers to the emotional ties to teachers and school } \\
\text { officials }\end{array}$ & $\begin{array}{l}\text { The quality of the bond between students and } \\
\text { their classmates }\end{array}$ \\
\hline Commitment & $\begin{array}{l}\text { The desire to succeed and the degree of commitment to } \\
\text { academic pursuits }\end{array}$ & $\begin{array}{l}\text { The desire to succeed and the degree of } \\
\text { commitment to academic pursuits }\end{array}$ \\
\hline Belief & Believing that school rules are fair and evenly enforced & Believing that teachers treat all students fairly \\
\hline $\begin{array}{l}\text { Involvement } \\
\text { or } \\
\text { Performance }\end{array}$ & $\begin{array}{l}\text { School performance, attendance and attentiveness in the } \\
\text { classroom }\end{array}$ & $\begin{array}{l}\text { Performance in tests taken in first grade of } \\
\text { secondary school }\end{array}$ \\
\hline
\end{tabular}


Table 2. Distribution of Social Bond elements, background variables and indicators of juvenile delinquency and early school-leaving

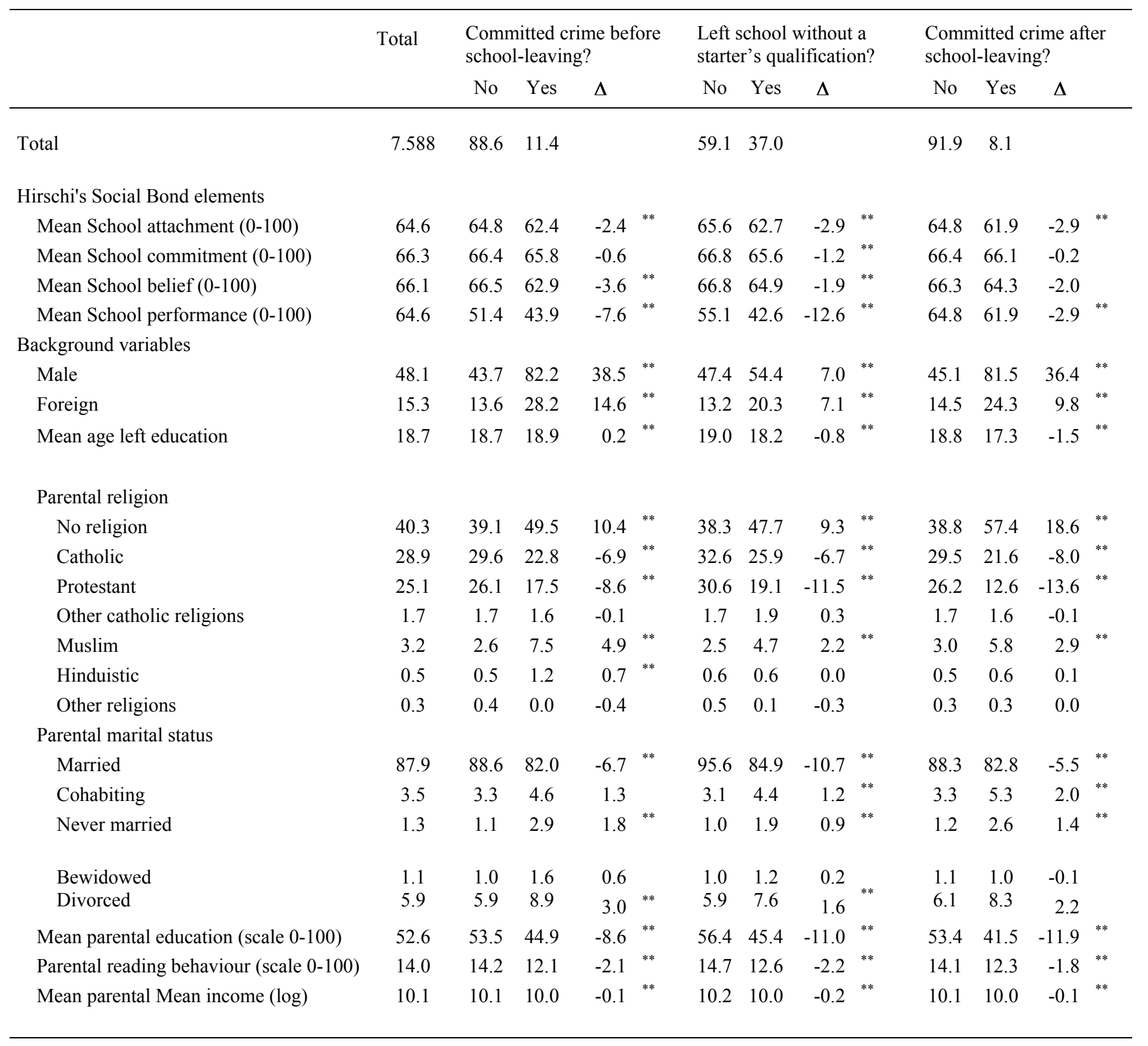

$* * \mathrm{p}<=0.01 * \mathrm{p}<=0.05$ 
Table 3. Logistic regression effects of the four elements of Social Bonding on crime before school-leaving, early school-leaving and crime after school-leaving

\begin{tabular}{|c|c|c|c|c|c|c|c|c|c|c|c|c|c|c|c|c|c|c|}
\hline & \multicolumn{4}{|c|}{$\begin{array}{c}\text { Committed crime before } \\
\text { school-leaving? }\end{array}$} & \multicolumn{6}{|c|}{ Left school without a starter's qualification? } & \multicolumn{8}{|c|}{ Committed crime after school-leaving? } \\
\hline & (1) & & $(2)$ & & (3) & & (4) & & $(5$ & & (6) & & (7) & & $(8)$ & & (9) & \\
\hline School attachment $(0-100)$ & -0.004 & & 0.002 & & -0.008 & $* *$ & -0.005 & $*$ & -0.005 & $*$ & -0.010 & $* *$ & -0.005 & & -0.006 & & -0.006 & \\
\hline School commitment $(0-100)$ & 0.001 & & -0.005 & & -0.001 & & -0.004 & & -0.004 & & 0.004 & & -0.001 & & 0.000 & & 0.000 & \\
\hline School belief $(0-100)$ & -0.008 & $* *$ & -0.007 & $* *$ & -0.003 & $*$ & -0.002 & & -0.002 & & 0.000 & & 0.000 & & 0.002 & & 0.002 & \\
\hline School performance $(0-100)$ & -0.021 & $* *$ & -0.015 & $* *$ & -0.042 & $* *$ & -0.037 & $* *$ & -0.037 & $* *$ & -0.026 & $* *$ & -0.020 & $* *$ & -0.017 & $* *$ & -0.011 & $* *$ \\
\hline Age leaving school & 0.067 & $* *$ & 0.079 & $* *$ & -0.383 & $* *$ & -0.388 & $* *$ & -0.395 & $* *$ & -0.583 & $* *$ & -0.611 & $* *$ & -0.655 & $* *$ & -0.585 & $* *$ \\
\hline $\begin{array}{l}\text { Controls for background } \\
\text { variables }^{\text {a) }}\end{array}$ & no & & yes & & no & & yes & & yes & & no & & yes & & yes & & yes & \\
\hline $\begin{array}{l}\text { Crime before school-leaving } \\
\text { Early School-leaving }\end{array}$ & & & & & & & & & 0.620 & $* *$ & & & & & 1.374 & $* *$ & $\begin{array}{l}1.290 \\
0.793\end{array}$ & ** \\
\hline $\mathrm{R} 2$ & $3.9 \%$ & & $19.7 \%$ & & $21.6 \%$ & & $26.3 \%$ & & $27.0 \%$ & & $18.8 \%$ & & $31.3 \%$ & & $34.8 \%$ & & $36.1 \%$ & \\
\hline
\end{tabular}

** $\mathrm{p}<=0.01, * \mathrm{p}<=0.05$; log odds ratios reported; $\mathrm{R} 2$ is the Nagelkerke $\mathrm{R} 2$; sample size is 7,588 for all models

a) Controlled for gender, ethnicity, parental religion, parental marital status, parental education, parental reading behaviour, parental income and missing values. 
Table 4. Logistic regression effects for predicting the interaction effect of the four elements of Social Bonding on crime before school-leaving, early school-leaving and crime after school-leaving (unstandardized coefficients)

\begin{tabular}{|c|c|c|c|c|c|c|c|c|c|c|c|c|}
\hline & \multicolumn{4}{|c|}{ Early school-leaving } & \multicolumn{8}{|c|}{ Crime after school-leaving } \\
\hline & $(1)$ & & $(2)$ & & (3) & & $(4)$ & & $(5)$ & & $(6$ & 6) \\
\hline School attachment $(0-100)$ & -0.005 & * & -0.004 & & -0.006 & & -0.007 & & 0.002 & & 0.001 & \\
\hline School commitment $(0-100)$ & -0.004 & & -0.005 & * & 0.000 & & -0.002 & & 0.006 & & 0.004 & \\
\hline School belief $(0-100)$ & -0.002 & & -0.002 & & 0.002 & & 0.001 & & -0.001 & & -0.002 & \\
\hline School performance $(0-100)$ & -0.037 & $* *$ & -0.040 & $* *$ & -0.011 & $* *$ & -0.013 & $* *$ & -0.019 & $* *$ & -0.020 & $* *$ \\
\hline Age leaving school & -0.395 & $* *$ & -0.401 & $* *$ & -0.585 & $* *$ & -0.588 & $* *$ & -0.594 & $* *$ & -0.597 & $* *$ \\
\hline Controls for background variables ${ }^{\mathrm{a})}$ & yes & & yes & & yes & & yes & & yes & & yes & \\
\hline Crime before school-leaving & 0.620 & $* *$ & -0.642 & & 1.290 & $* *$ & 0.324 & & 1.280 & $* *$ & 0.325 & \\
\hline Early School-leaving & & & & & 0.793 & $* *$ & 0.774 & $* *$ & 1.154 & & 1.216 & \\
\hline Crime before $*$ School attachment & & & -0.009 & & & & 0.003 & & & & 0.003 & \\
\hline Crime before $*$ School commitment & & & 0.010 & & & & 0.005 & & & & 0.006 & \\
\hline Crime Before $*$ School belief & & & 0.001 & & & & 0.002 & & & & 0.002 & \\
\hline Crime before $*$ School performance & & & 0.024 & $* *$ & & & 0.007 & & & & 0.006 & \\
\hline Early School Leaving * School attachment & & & & & & & & & -0.011 & & -0.011 & \\
\hline Early School Leaving * School commitment & & & & & & & & & -0.009 & & -0.009 & \\
\hline Early School Leaving * School belief & & & & & & & & & 0.005 & & 0.005 & \\
\hline Early School Leaving * School performance & & & & & & & & & 0.012 & * & 0.012 & \\
\hline $\mathrm{R} 2$ & $27.0 \%$ & & $27.5 \%$ & & $36.1 \%$ & & $36.1 \%$ & & $36.2 \%$ & & $36.3 \%$ & \\
\hline
\end{tabular}

$* * \mathrm{p}<=0.01, * \mathrm{p}<=0.05 ; \log$ odds ratios reported; R2 is the Nagelkerke R2; sample size is 7,588 for all models

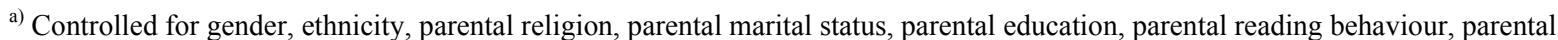
income and missing values. 
Figure 1: Probability function of the effect of school performance on early school-leaving by involvement in crime before left school or not.

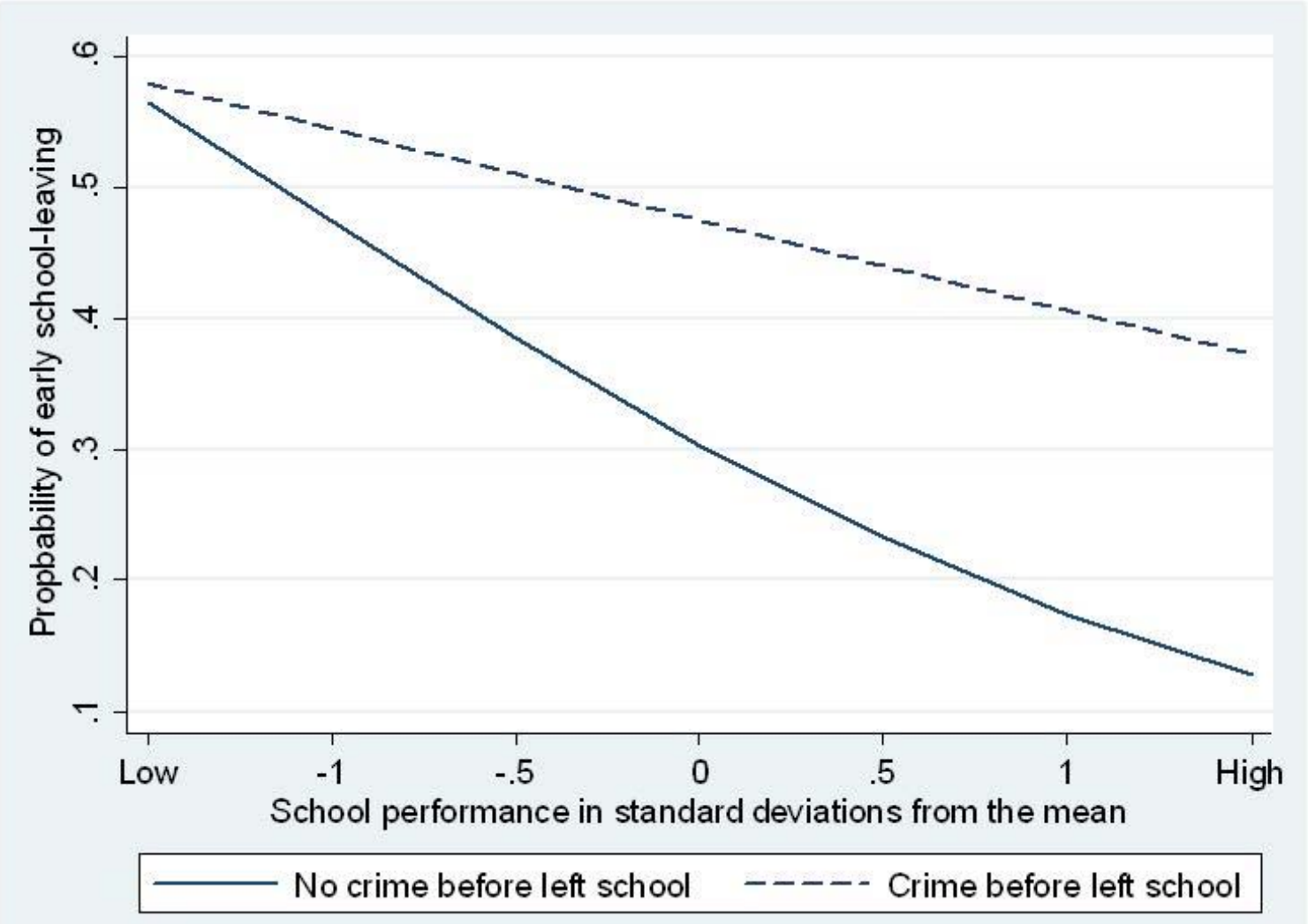




\section{Appendix}

Figure A The Dutch educational system

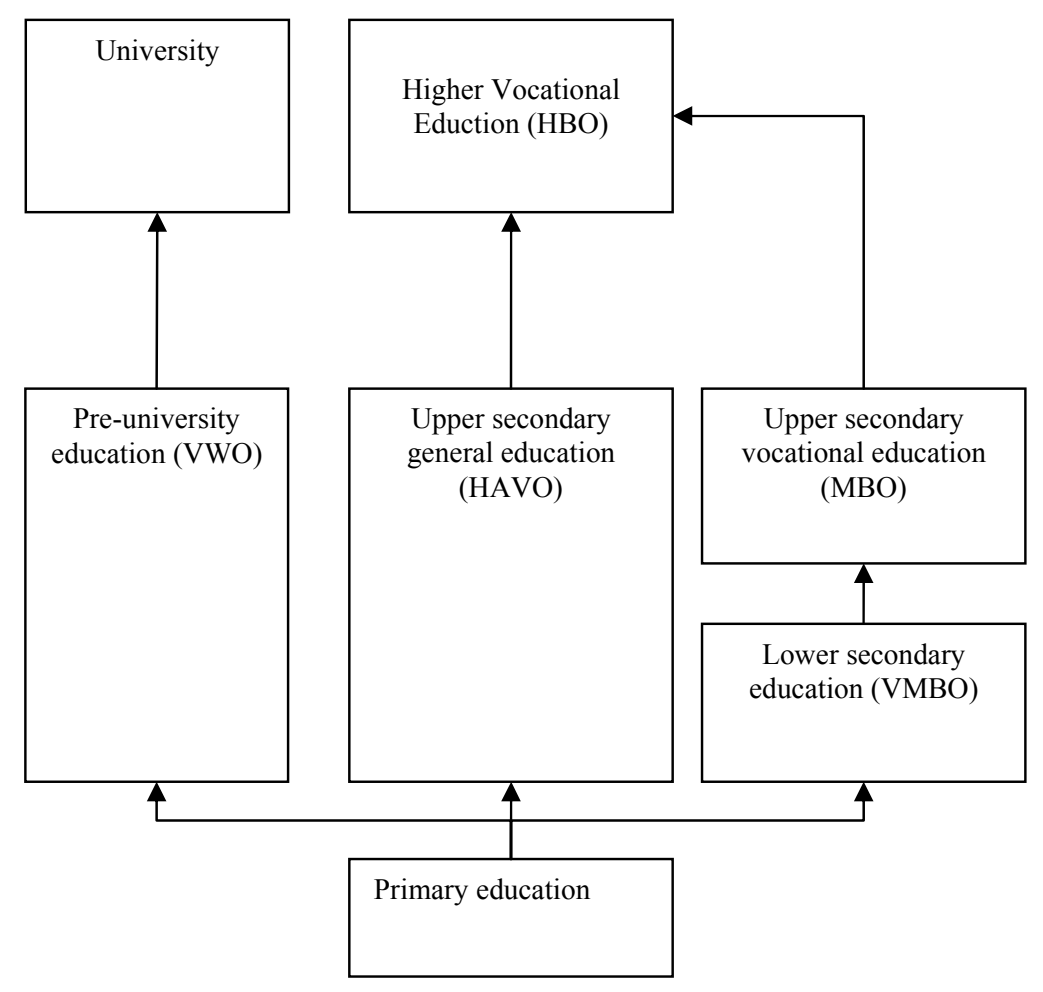


Table B Item listing for Social Bonds

\section{School Attachmen}

In our class students are nice to each other

In our class students help each other

In our class students treat each other fair

In our class there is a pleasant atmosphere

In our class students are accepted as they are

The atmosphere at my school is pleasant

In our class students trust each other

I get along very well with my classmates

I like the classmates in this school better than my classmates in primary school

I like the teachers in this school better than my teachers in primary school

School Commitment

I study just much harder when I'm worried about my report card

I study much better at home when I'm worried about failing

I find it very important to get a good report card

When I study I demand very much of myself

I always try to do my homework as well as possible

I always keep trying until I succeed

I always tell my parents about good grades immediately

I study much harder when I have a test

I would very much like to be the best in my class

School Belief

In our class teachers treat you fair

In our class teachers are really interested in the students

School Performance

Based on test scores on three subtests taken in de first

months of secondary school that measure the students'

aptitude in arithmetic/mathematics. text comprehension and information processing skills

$\begin{array}{rrrrr}\text { N } & \text { Min } & \text { Max } & \text { Mean } & \text { Sd } \\ 7104 & 1 & 5 & 3.482 & 0.872 \\ 7102 & 1 & 5 & 3.471 & 0.832 \\ 7091 & 1 & 5 & 3.237 & 0.921 \\ 7078 & 1 & 5 & 3.982 & 0.995 \\ 7061 & 1 & 5 & 3.576 & 1.046 \\ 7116 & 1 & 5 & 3.832 & 0.891 \\ 7063 & 1 & 5 & 3.386 & 0.917 \\ 7115 & 1 & 5 & 3.763 & 0.909 \\ 7123 & 1 & 5 & 3.366 & 1.106 \\ 7113 & 1 & 5 & 3.609 & 0.787 \\ & & & & \\ 6973 & 1 & 4 & 3.056 & 0.823 \\ 6970 & 1 & 4 & 3.118 & 0.773 \\ 6971 & 1 & 4 & 3.433 & 0.696 \\ 6946 & 1 & 4 & 2.241 & 0.784 \\ 6965 & 1 & 4 & 3.094 & 0.820 \\ 6965 & 1 & 4 & 2.605 & 0.945 \\ 6980 & 1 & 4 & 3.392 & 0.788 \\ 6999 & 1 & 4 & 2.513 & 0.857 \\ 6974 & 1 & 4 & 1.921 & 0.913 \\ & & & & \\ 7034 & 1 & 5 & 3.810 & 1.031 \\ 7016 & 1 & 5 & 3.478 & 0.991 \\ 7588 & 0 & 1 & 0.500 & 0.279\end{array}$


Table C OLS regressions for predicting the four elements of Social Bonding (standadized coefficients)

\begin{tabular}{|c|c|c|c|c|c|c|c|c|}
\hline & $\begin{array}{c}\text { School } \\
\text { Attachmen } \\
\end{array}$ & & $\begin{array}{c}\text { School } \\
\text { Commitmen } \\
\end{array}$ & & $\begin{array}{c}\text { School } \\
\text { Belief } \\
\end{array}$ & & $\begin{array}{c}\text { School } \\
\text { Performanc }\end{array}$ & \\
\hline Male & $-0.058 *$ & $* *$ & -0.001 & & -0.032 & ** & -0.016 & \\
\hline Ethnic minority & -0.023 & & 0.075 & $* *$ & -0.038 & ** & -0.047 & $* *$ \\
\hline Parental religion: Catholic & 0.006 & & -0.021 & & -0.004 & & 0.038 & $* *$ \\
\hline Parental religion: Protestant & $0.030 *$ & * & -0.096 & ** & -0.006 & & 0.045 & ** \\
\hline Parental religion: Other & $-0.030 *$ & * & 0.070 & ** & -0.003 & & 0.004 & \\
\hline Parental marital status: Never Married & -0.011 & & -0.001 & & -0.011 & & -0.010 & \\
\hline Parental marital status: Divorced & $-0.029 *$ & * & -0.048 & ** & -0.030 & $*$ & 0.014 & \\
\hline Average parental educational level (scale $0-1$ ) & $0.032 *$ & ** & 0.045 & ** & -0.031 & * & 0.199 & $* *$ \\
\hline Parental reading behaviour (scale $0-1$ ) & $0.029 *$ & * & -0.021 & & -0.006 & & 0.081 & ** \\
\hline Parental income in 2005 (log) & 0.021 & & 0.013 & & 0.004 & & 0.046 & $* *$ \\
\hline Controls for missing values & yes & & yes & & yes & & yes & \\
\hline $\mathrm{R}^{2}$ & $3.6 \%$ & & $2.9 \%$ & & $0.8 \%$ & & $8.9 \%$ & \\
\hline
\end{tabular}

$* \mathrm{p}<0.05 . * * \mathrm{p}<0.01$ 